\title{
Effects of new bus and rail rapid transit systems - an international review
}

\author{
Ingvardson, Jesper Bláfoss; Nielsen, Otto Anker
}

Published in:

Transport Reviews

Link to article, DOI:

10.1080/01441647.2017.1301594

Publication date:

2018

Document Version

Peer reviewed version

Link back to DTU Orbit

Citation (APA):

Ingvardson, J. B., \& Nielsen, O. A. (2018). Effects of new bus and rail rapid transit systems - an international review. Transport Reviews, 38(1), 96-116. https://doi.org/10.1080/01441647.2017.1301594

\section{General rights}

Copyright and moral rights for the publications made accessible in the public portal are retained by the authors and/or other copyright owners and it is a condition of accessing publications that users recognise and abide by the legal requirements associated with these rights.

- Users may download and print one copy of any publication from the public portal for the purpose of private study or research.

- You may not further distribute the material or use it for any profit-making activity or commercial gain

- You may freely distribute the URL identifying the publication in the public portal 


\title{
Effects of new bus and rail rapid transit systems - an international review
}

\begin{abstract}
Cities worldwide are implementing modern transit systems to improve mobility in the increasingly congested metropolitan areas. Despite much research on the effects of such systems, a comparison of effects across transit modes and countries has not been studied comprehensively. This paper fills this gap in the literature by reviewing and comparing the effects obtained by 86 transit systems around the world including Bus Rapid Transit (BRT), Light Rail Transit (LRT), metro, and heavy-rail transit systems. The analysis is two-fold by analysing i) the direct operational effects related to travel time, ridership, and modal shifts, and ii) the indirect strategic effects in terms of effects on property values and urban development. The review confirms the existing literature suggesting that BRT can attract many passengers if travel time reductions are significantly high. This leads to attractive areas surrounding the transit line with increasing property values. Such effects are traditionally associated with attractive rail-based public transport systems. However, a statistical comparison of 41 systems did not show significant deviations between effects on property values resulting from BRT, LRT, and metro systems, respectively. Hence, this paper indicates that large strategic effects can be obtained by implementing BRT systems at a much lower cost.
\end{abstract}

Keywords: Bus Rapid Transit (BRT), Light Rail Transit (LRT), property values, traffic impacts, urban development, public transport systems, system comparison.

\section{Introduction}

Public transport systems are important for improving mobility and relieving traffic congestion in the increasingly congested metropolitan areas. Hence, cities around the world are searching for the most efficient way of upgrading their public transport networks. This involves planning the appropriate cost-effective system for a given context ranging from low-cost Bus Rapid Transit systems (BRT) over modern Light Rail Transit (LRT) to more costly, but highly attractive metro or urban railway systems. With the increasing focus on cost-effectiveness in transport investments it is important to know the possible effects when upgrading public transport networks. This reveals the strengths and weaknesses of various systems including the drivers for ensuring that the systems will be attractive for passengers.

Over the past decades BRT and LRT systems have experienced increased popularity due to their ability to deliver attractive service levels at a lower cost than those of heavy rail and metro systems. In Europe the first modern light rail system was opened in 1985 in Nantes. Due to the success of the system, several other French cities implemented light rail systems in the following years in corridors where the ridership was too small to justify an expensive metro solution, but where there was a wish to upgrade the existing bus operations (Bottoms, 2003). In Latin America several cities have focused on BRT systems, primarily due to the lower construction costs. The first systems were established in the 1970s and 1980s in the aftermath of the successful Rede Integrada de 
Transporte in Curitiba, Brazil, which was established in 1974. The number of BRT systems has increased significantly, particularly within the last 10 years, and currently, 200 cities have BRT systems serving 33 million passengers every day, $88 \%$ of them located in Latin America or Asia (“Global BRT Data," 2016). However, BRT systems are also becoming increasingly popular in Europe, where they are often also referred to as Buses with High Level of Service (BHLS) (Hidalgo \& Muñoz, 2014). Hence, successful systems now exist in many European cities including Paris, Nantes, Rouen, Madrid, Amsterdam and many others (Finn et al., 2011).

The systems vary greatly between countries, especially for BRT which is not a strict definition. Much literature therefore focuses on the design concepts and system characteristics of BRT (Levinson, Zimmerman, Clinger, \& Rutherford, 2002), (Wright \& Hook, 2007), (Hensher \& Golob, 2008), (Nikitas \& Karlsson, 2015), (Wirasinghe et al., 2013), and others. Some studies investigate the individual attractiveness of such characteristics on ridership for BRT (Currie \& Delbosc, 2011) and for LRT (Currie, Ahern, \& Delbosc, 2011), while studies also exist that compare across the two modes (Currie \& Delbosc, 2013). In addition, many single transit systems have been analysed in terms of effects on ridership, urban development and property values (Cao \& Schoner, 2014; Cervero, 1984; Dueker \& Bianco, 1999; Knowles, 1996, and many others). These studies include a review of the relevant literature, but often focus on either BRT or LRT systems only.

A few papers review the urban development effects focusing on either BRT (Currie, 2006b; Stokenberga, 2014) or LRT systems (Knowles \& Ferbrache, 2015). In (Ryan, 1999) the effects of property values are compared across the modes of light rail, heavy rail and highways while also focusing on methodological differences between studies throughout the 1960s-1990s. Several other studies compare the effects between BRT and metro in Beijing (Ma, Ye, \& Titheridge, 2014) and Guangzhou (Salon, Wu, \& Shewmake, 2014), and between BRT and LRT in Pittsburgh (V. Perk, Mugharbel, \& Catalá, 2010). The limitations of these studies consist in them either focusing on the effects of a single public transport mode (Currie, 2006b; Knowles \& Ferbrache, 2015; Stokenberga, 2014), not including the three main high-class public transport modes of metro, LRT and BRT (Ryan, 1999), and/or only reviewing a few studies (Ma et al., 2014; V. Perk et al., 2010; Salon et al., 2014).

This paper fills the gap in the literature by reviewing the effects of a large sample of 86 transit systems including BRT, LRT and metro/heavy rail. The effects have been analysed in terms of changes in demand, including modal shifts (section 2), and strategic effects in terms of changes in property values (section 3). Furthermore, section 4 presents a number of examples on the impacts on city development. Section 5 discusses the methodological considerations and points to future work while section 6 concludes the review by highlighting the impacts caused by the various public transport modes and thus compares the mode-dependent effects.

\section{Traffic impacts}


One of the main reasons for upgrading and extending public transport is to obtain travel time benefits for the users of the system. It is therefore essential to study the potential travel time improvements of metro, LRT and BRT, respectively. In urban areas the construction of a metro provides the biggest travel time benefits as metros run in fully segregated right-of-way as opposed to light rail systems and BRT which are often constructed at street level with crossings. High speeds with light rail systems and BRT can however be obtained by implementing dedicated right-of-way, signal priority, and other Advanced Public Transport Systems (APTS) elements (Ingvardson, Jensen, $\&$ Nielsen, 2015). The various elements of BRT make it easy to adapt the concept to a local context. However, this flexibility may lead to the implementation of half measures where one or often several elements have been left out to save construction costs (Rodríguez \& Targa, 2004). As a consequence, big variations exist between the various systems around the world. Some systems are just conventional bus lines that have been upgraded with a few BRT elements, for instance bus lanes, signal priority or special vehicles. Other systems contain entire corridors with completely segregated bus lanes, station-like bus stops with ticketing systems on the platform, real-time information and signal priority along the entire corridor. Such large differences between system solutions make it difficult to establish general impacts as they will depend on the design of the system and the degree of improvement with respect to the original solution.

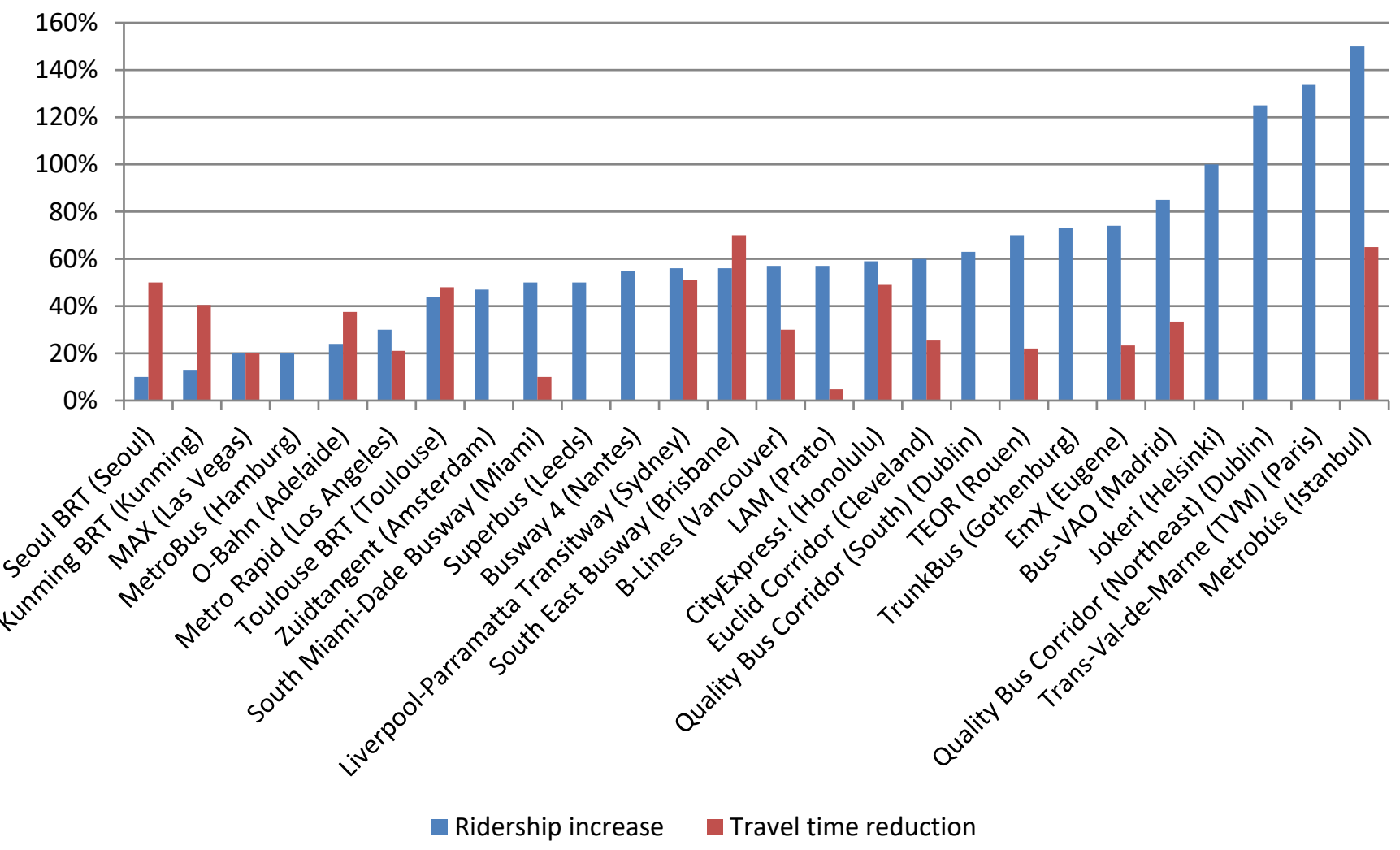

Figure 1: Relationship between travel time reductions and increase in ridership for selected BRT systems.

Figure 1 clearly shows the large variation in ridership effects of various BRT systems. Some of the largest increases in ridership were obtained by Metrobús in Istanbul, where a thorough implementation of BRT elements, including an almost fully segregated infrastructure, ensured travel time reductions of $65 \%$ resulting in $150 \%$ more passengers (Yazici, Levinson, Ilicali, Camkesen, \& 
Kamga, 2013). In Paris, the Trans-Val-de-Marne route was reported to gain an increase of $134 \%$ in ridership after opening; this increase however possibly included effects of general traffic growth as it was measured over a longer period of time. The system induced significant improvements to travel time in terms of 16 minutes decrease in travel time through the $20 \mathrm{~km}$ corridor (Finn et al., 2011). In Dublin, the implementation of Quality Bus Corridors resulted in significantly increased ridership of up to $125 \%$ for the northeastern Malahide corridor (Finn et al., 2011) and 63\% for the southern Stillorgan corridor (O’Mahony, 2002). This despite the corridors not being full BRT systems as they mainly included bus lanes (shared with taxis and bicyclists) and some service improvements including higher frequency and bus priority. This resulted in significantly increased bus travel speeds and faster than car travel speeds during peak hours, however, primarily because of simultaneous closure of road traffic lanes (O’Mahony, 2002). In Madrid, the Bus-VAO system obtained a 33\% travel time reduction due to its running almost fully segregated. Together with strong connections to the metro network ridership increased by $85 \%$ (Heddebaut, Finn, Rabuel, \& Rambaud, 2010). Several systems were implemented in the United States with dedicated infrastructure and strong branding resulting in increased travel speed and ridership, e.g. the EmX BRT system in Eugene which attracted 74\% more passengers by implementing off-board fare collection and dedicated busways. Combined with strong branding it resulted in a $23 \%$ travel time reduction. The Cleveland Euclid corridor BRT resulted in a $60 \%$ ridership increase after two years of operation due to a largely segregated system ensuring a $34 \%$ speed increase (Weinstock, Hook, Replogle, \& Cruz, 2011). In Honolulu, a 49\% travel time reduction resulted in a 59\% ridership increase after one year of service (City and County of Honolulu, 2001).

And in Miami, the South Miami-Dade Busway resulted in a 50\% increase in ridership resulting from a travel time reduction of less than 10\% (National BRT Institute, 2003). The system incorporated fully segregated busways and special stations equipped with information and shelters. In Europe, similar impacts were obtained in several cities, including Rouen, Prato and Nantes, which saw passenger ridership increases in the same ranges around 60\%. In Prato, Italy, a relatively small improvement in travel time resulted in a big increase in ridership due to a simultaneous doubling of frequency and strong branding (Heddebaut et al., 2010). The systems in Nantes and Rouen both included almost full segregation, special branding and some pre-board fare collection resulting in high levels of reliability and ridership increases of 55-70\%. Also in Australia several systems obtained large positive effects. In Brisbane, ridership increased by $56 \%$ due to a fully segregated system with signal priority and high frequency resulting in a 70\% travel time reduction (Currie, 2006a). The Liverpool-Parramatta Transitway in Sydney implemented dedicated busways and bus lanes as well as Intelligent Transport Systems (ITS) elements including traffic signal priority, real time passenger information and some off-board fare collection (Currie, 2006a). The implementation ensured a 51\% travel time reduction and $56 \%$ ridership increase.

In other places, only smaller effects were seen despite implementing thorough and high-class systems with travel time reductions of 40-50\%. In Seoul, the effect of the BRT on ridership was only a $10 \%$ increase within one year after opening, which however should be compared to a general 
decline in ridership for buses during the same period as well as a very high attractiveness of the Seoul subway carrying 35\% of all trips in Seoul (Cervero \& Kang, 2011). Hence, the public transport system was quite attractive already before implementing BRT. In Kunming, ridership increased by $13 \%$ at its opening, but an increase of $100 \%$ was seen five years after opening (Darido, 2006). The Las Vegas MAX bus line resulted in a 25\% ridership increase when implementing segregation in $60 \%$ of the corridor, off-board fare collection and specially branded buses resulting in a travel time reduction of 20\% (Weinstock et al., 2011). The Metro Rapid system in Los Angeles did not feature segregated infrastructure, but relied on efficient route design with longer stop spacings, signal priority, special branding of vehicles and stations that allowed for faster dwell times (Hoffman, 2008). The average travel time reductions of $21 \%$ resulted in increased ridership of $15-20 \%$, for some corridors up to 33\% (Levinson et al., 2002). In Hamburg, the Metrobus system improved the existing bus line by implementing segregation on $27 \%$ of the corridor, some branding, strong integration and signal priority resulting in minor increases to travel speed and ridership (Finn et al., 2011).

These results show that all systems had notable effects on travel time and thus ridership. Systems that included thorough implementations of many BRT elements such as dedicated bus lanes on most segments, signal priority, pre-board fare collection and special branding obtained significant improvements of travel time and ridership. When combined, these elements can notably improve not only travel times, but also reliability which is often difficult to improve in bus operations, hence causing bus bunching, e.g. in Gothenburg (Heddebaut et al., 2010) and Copenhagen (Ingvardson et al., 2015). The results however also show that effects vary notably between systems and cannot only be explained by travel time improvements. Several other factors influence the effects such as the attractiveness of the existing public transport network and the car traffic conditions, including road congestion and car use restrictions. But also factors related to the local context seem to play a role which has not been fully investigated in the reviewed studies. Hence, there seems to be a knowledge gap regarding the influence and importance of factors not related to the actual improvement of the public transport line which may explain the attractiveness of the public transport line.

\subsection{Modal shift}

The increased ridership when implementing new public transport systems is caused by both induced traffic and a mode shift effect. In several places it has thus been observed that the new system has attracted users who previously used other modes, e.g. cars. Mode shifts from cars are especially important for two major reasons. Firstly, shifting car users to public transport will relieve congestion in the often very congested road network in large metropolitan areas. Secondly, there is an increasing focus by policy makers to promote sustainable transport for environmental reasons. In Table 1 the mode shift from cars is listed for a range of public transport systems. The systems mentioned gave rise to significant mode shifts from other modes, especially from buses, e.g. in Copenhagen and 
Istanbul (Vuk, 2005; Yazici et al., 2013), from bicycles in Utrecht (Finn et al., 2011) and from metro in Stockholm (Finn et al., 2011).

\begin{tabular}{|c|c|c|}
\hline System & Mode shift ${ }^{1}$ & Source \\
\hline Metrobús (BRT, Istanbul) & $4-9 \%$ & (Yazici et al., 2013) (Alpkokin \& Ergun, 2012) \\
\hline Stombuss (Blue buses) (BRT, Stockholm) & $5 \%$ & (Finn et al., 2011) \\
\hline Trans-Val-de-Marne (BRT, Paris) & $8 \%$ & (Finn et al., 2011) \\
\hline BRT Line 1 (BRT, Beijing) & $12 \%$ & (Deng \& Nelson, 2013) \\
\hline Jokeri line (BRT, Helsinki) & $12 \%$ & (Finn et al., 2011) \\
\hline Trans Jakarta (BRT, Jakarta) & $14 \%$ & (Ernst, 2005) \\
\hline Bus-VAO (BRT, Madrid) & $15 \%$ & (Finn et al., 2011) \\
\hline QBC - Malahide corridor (BRT, Dublin) & $17 \%$ & (O’Mahony, 2002) \\
\hline Kent Thameside (BRT, Kent) & $19 \%$ & (Deng \& Nelson, 2011) \\
\hline Orange Line (BRT, Los Angeles) & $19 \%$ & (Callaghan \& Vincent, 2007) \\
\hline South Miami-Dade Busway (BRT, Miami) & $21 \%$ & (National BRT Institute, 2003) \\
\hline Nantes BHLS (BRT, Nantes) & $29 \%$ & (Rabuel, 2010) \\
\hline O-Bahn (BRT, Adelaide) & $40 \%$ & (Currie \& Sarvi, 2012) \\
\hline Angers Tramway (LRT, Angers) & $0 \%$ & (Olesen, 2014) \\
\hline Midland Metro (LRT, Birminigham) & $13 \%$ & (Harper \& Bird, 2000) \\
\hline Nantes LRT (LRT, Nantes) & $17-37 \%$ & (Lee \& Senior, 2013) \\
\hline Croydon (LRT, Croydon) & $19 \%$ & (Copley, Thomas, Maunsell, \& Georgeson, 2002) \\
\hline Metrolink (LRT, Manchester) & $21 \%$ & (Knowles, 1996) \\
\hline Blue Line (LRT, Los Angeles) & $21 \%$ & (Lee \& Senior, 2013) \\
\hline Sheffield Supertram (LRT, Sheffield) & $22 \%$ & (Lee \& Senior, 2013) \\
\hline Blue Line (LRT, San Diego) & $30 \%^{2}$ & (Lee \& Senior, 2013) \\
\hline Orange Line (LRT, San Diego) & $50 \%^{2}$ & (Lee \& Senior, 2013) \\
\hline Avg. 14 European systems (LRT) & $11 \%$ & (Hass-Klau, Crampton, Biereth, \& Deutsch, 2003) \\
\hline Copenhagen Metro (Metro, Copenhagen) & $8-14 \%$ & (Vuk, 2005) \\
\hline BART (Metro, San Francisco) & $35 \%$ & (Richmond, 1991) \\
\hline
\end{tabular}

Table 1: Mode shift from car traffic for selected public transport systems.

Again, effects vary notably across all systems. However, it should be observed that several of the figures represent relatively small lines. For instance, $22 \%$ of the passengers on the Sheffield Supertram were former car users. When comparing with the market share of LRT of $17 \%$ the mode shift was only around $4 \%$. This is general for all studies as the numbers represent the percent of passengers who previously travelled by car. In the case of San Diego Trolley 30\% of the passengers after the opening of the first line in 1981 were former car users. In 1990 the share was estimated at $50 \%$ after the opening of the second line in the same light rail system (Lee \& Senior, 2013). Another example worth mentioning was the $19 \%$ mode shift obtained for the Los Angeles Orange Line, which was established in a new segregated corridor. A passenger survey showed the same level of satisfaction with the BRT line as with the Gold Line LRT and a higher level of satisfaction than with the Blue Line LRT. This was probably due to the high level of service thanks to the segregated

\footnotetext{
1 Percent of passengers who previously travelled by car.

2 Mode shift for commuting trips based on travel surveys.
} 
infrastructure (Cain, Flynn, McCourt, \& Reyes, 2009). However, the Blue Line also obtained a similarly large mode shift (21\%) of passengers from car traffic which in absolute numbers was significantly larger, since the line serves three times as many passengers than the Orange Line. On the other hand, no significant shift from car traffic was obtained for the LRT system in Angers, probably due to the fact that the LRT did not reduce the travel time as compared to the existing bus lines. Instead the LRT was implemented to attach the central urban areas to a high-class public mode of transport (Olesen, 2014).

In general, the findings show that both BRT and LRT systems obtained a sufficiently high attractiveness to attract users from other modes of transport, including former car users. This could indicate that the quality of the upgrade is more important than the choice of system. But as the capacity is often highest for metro systems and lowest for BRT systems a similar mode shift will induce different impacts on car traffic, i.e. metro systems can have larger impacts on road congestion than BRT systems. However, exceptions do exist, e.g. the Metrobús corridor in Istanbul which carries 600,000 passengers per day and hence is running at a very high capacity (Yazici et al., 2013). Hence, in order to obtain notable impacts on car traffic attractive high-capacity systems are needed.

\section{Strategic effects}

Generally, major improvements to public transport systems will, all other things being equal, result in significant changes in real estate prices (Pagliara \& Papa, 2011). Many examples exist of how large infrastructure projects have had a positive influence on urban development, as the accessibility of an area is increased when the transport system is improved resulting in lower travel times. This makes the areas more attractive which is reflected in higher real estate prices for existing buildings, and it also makes the areas more attractive for investors resulting in new urban development. The strategic effects of extending the public transport network may be bigger than the pure traffic effects (Al-Dubiki \& Mees, 2010). Many analyses attempt to quantify the effects of real estate prices on various transport systems. Tables 2-4 provide an overview of the influence of BRT, LRT and metro systems on real estate prices.

\begin{tabular}{|lrl|}
\hline \multicolumn{1}{c}{ System } & Property value change & \multicolumn{1}{c}{ Source } \\
\hline BRT Line 1 (Beijing) & 0 & (Ma et al., 2014) \\
\hline Seoul BRT (Seoul) & $+5-10 \%$ & (Cervero \& Kang, 2011) \\
\hline TEOR (Rouen) & $+10 \%$ & (Martínez \& Viegas, 2009) \\
\hline TransMilenio (Bogotá) & $+11-13 \%$ & (Perdomo Calvo, Mendoza, Baquero-Ruiz, \& \\
& & Mendieta-Lopez, 2007), (Rodríguez \& Targa, 2004) \\
\hline East Busway (Pittsburgh, USA) & $+16 \%$ & (V. Perk et al., 2010) \\
\hline South-East Busway (Brisbane) & $+20 \%$ & (Levinson, Zimmerman, Clinger, Rutherford, et al., \\
& $2003)$ \\
\hline Guangzhou BRT (Guangzhou) & $+0-30 \%$ & (Suzuki, Cervero, \& Iuchi, 2013), (Salon et al., \\
& $2014)$
\end{tabular}

Table 2: Effects of BRT systems on property values. 


\begin{tabular}{|lrl}
\hline \multicolumn{1}{c}{ System } & Property value change & \multicolumn{1}{c}{ Source } \\
\hline Supertram (Sheffield, UK) & 0 & (Dabinett, Gore, Haywood, \& Lawless, 1999) \\
\hline $\begin{array}{l}\text { Sacramento RT Light Rail (Sacramento, } \\
\text { USA) }\end{array}$ & 0 & (Landis, Guhathakurta, Huang, Zhang, \& Fukuji, \\
\hline Metrolink light rail (Manchester, UK) & 0 & (Martínez \& Viegas, 2009) \\
& $-6 \%$ & (Forrest, Glen, \& Ward, 1996) \\
\hline MetroRail (Houston, USA) & + - & (Pan, 2012) \\
\hline Eastside MAX (Portland, USA) & $+0-10.6 \%$ & (Al-Mosaind, Dueker, \& Strathman, 1993), (Chen, \\
& Rufolo, \& Dueker, 1998) \\
\hline San Diego Trolley (San Diego, USA) & $+0-17.3 \%$ & (Cervero \& Duncan, 2002b; Landis et al., 1995) \\
\hline Buffalo Metro Rail (Buffalo, USA) & $+2-5 \%$ & (Hess \& Almeida, 2007) \\
\hline Bybanen (LRT, Bergen) & $+4 \%$ & (Fredriksen, 2013) \\
\hline DART (Dallas, USA) & $+10-25 \%$ & (Weinstein \& Clower, 2002), \\
\hline Metro Light Rail (Phoenix, USA) & $+25 \%$ & (Golub, Guhathakurta, \& Sollapuram, 2012) \\
\hline Metrolink (St. Louis, USA) & $+32 \%$ & (Martínez \& Viegas, 2009) \\
\hline Tramlink (Croydon, UK) & + & (ATISREAL, Geofutures, UCL, \& Group, 2004) \\
\hline Docklands (London, UK) & + & (Knowles \& Ferbrache, 2015; Martínez \& Viegas, \\
& 2009) \\
\hline
\end{tabular}

Table 3: Effects of LRT systems on property values. Note: + denotes significant, but non-quantified positive effects, and +/denotes mixed positive and negative non-quantified effects.

\begin{tabular}{|c|c|c|}
\hline System & Property value change & Source \\
\hline Coaster (San Diego, USA) & $-7.1 \%$ & (Cervero \& Duncan, 2002b) \\
\hline Caltrain (San Francisco, USA) & 0 & (Landis et al., 1995) \\
\hline Miami metrorail (Miami, USA) & 0 & (Gatzlaff \& Smith, 1993) \\
\hline MARTA (Atlanta, USA) & $+/-$ & (Bollinger \& Ihlanfeldt, 1997) \\
\hline BART (San Francisco, USA) & $+0-4 \%$ & $\begin{array}{l}\text { (Landis, Zhang, \& Guhathakurta, 1994), (Landis et } \\
\text { al., 1995), (Dueker \& Bianco, 1999) }\end{array}$ \\
\hline Lindenwold line (Philadelphia, USA) & $+0-8 \%$ & (Voith, 1993) \\
\hline Tyne and Wear Metro (Newcastle, UK) & $+2 \%$ & (Pickett, 1984) \\
\hline Copenhagen Metro & $+3.8 \%$ & (Kolstrup, 2006) \\
\hline SEPTA (Philadelphia, USA) & $+3.8 \%$ & (Voith, 1991) \\
\hline MBTA (Boston, USA) & $+6-10 \%$ & (J. Armstrong \& Robert, 1994) \\
\hline Belfast suburban rail (Belfast) & $+8 \%$ & (Adair, McGreal, Smyth, Cooper, \& Ryley, 2000) \\
\hline Helsinki metro (Helsinki) & $+8 \%$ & (Hack, 2002) \\
\hline Seoul Subway (Seoul) & $+9 \%$ & (Bae, Jun, \& Park, 2003) \\
\hline PATCO (Philadelphia, USA) & $+10 \%$ & (Voith, 1991) \\
\hline Midway line (Chicago, USA) & $+17 \%$ & (McDonald \& Osuji, 1995) \\
\hline Metra (Chicago, USA) & $+20 \%$ & (Lin, 2002) \\
\hline Toronto subway (Toronto) & $+20 \%$ & (Hack, 2002) \\
\hline Jubilee Line Extension (London, UK) & + & (Jones et al., 2004; Martínez \& Viegas, 2009) \\
\hline Guangzhou Metro (Guangzhou) & + & (Salon et al., 2014) \\
\hline
\end{tabular}

Table 4: Effects of metro and heavy rail systems on property values. Note: + denotes significant, but non-quantified positive effects, and $+/$ - denotes mixed positive and negative non-quantified effects. 
There are thus big differences between the listed projects. There are two important factors that are important to highlight before comparing the figures.

Firstly, there is no general standardised method for the calculation of changes in real estate prices (Banister \& Thurstain-Goodwin, 2011). Consequently the different studies used a variety of methods of analysis and data sources (Munoz-Raskin, 2010). For example, different distances were used to define when a property was placed close to a station. However, the impact area was considered to be approximately $1000 \mathrm{~m}$ for residential properties and $400 \mathrm{~m}$ for commercial properties such as shops and offices (Banister \& Thurstain-Goodwin, 2011). There was however a high degree of variability since some studies analysed properties within a distance of 200-400 m (Hess \& Almeida, 2007) and others examined properties within a distance of 1,000 m (Rodríguez \& Mojica, 2009) or just indicated that the property was within an urban area served by a station (R. J. Armstrong \& Rodríguez, 2006; Voith, 1993).

Secondly, the projects were very dependent on local conditions (Martínez \& Viegas, 2009). This was observed even between corridors within the same study. In San Diego considerably higher sales prices (between $4 \%$ and $17 \%$ ) could be demonstrated for properties within walking distance of a light rail station, depending on the corridor in which the property was situated (Cervero \& Duncan, 2002b). In one of the corridors no relationship between price and distance to the station could be found. This was also reflected in a similar study of the effects of various systems in Los Angeles (Cervero \& Duncan, 2002a). Here the results varied considerably depending on the type of property (house, flat and commercial property) and station type (bus, metro and light rail). The same result was found in connection with the establishment of the LRT system in Phoenix where the results to a large extent depended on the types of dwellings (Golub et al., 2012). In Philadelphia very different effects were also found for different networks, since real estate prices for properties close to PATCO stations were $10 \%$ higher, whereas the prices of properties situated closer to SEPTA stations were only $4 \%$ higher than those of comparable properties. However, in this case the difference could be partly explained by other factors, one of them being that PATCO provided better travel times as compared to car and SEPTA (Voith, 1991).

When analysing the impacts on property values further, several findings were observed. For several of the systems the analyses showed that the effects occurred even before the system was implemented. The prices thus increased due to the expectation of improved accessibility. This was observed in connection with the establishment of the railway line between Chicago and the Midway Airport where the property prices rose by $17 \%$ within a distance of $800 \mathrm{~m}$ from the future stations. This observation was made three years before the connection actually opened (McDonald \& Osuji, 1995). A similar effect was observed in Seoul where the station distance only affected property values significantly prior to the opening of the line 5 subway (Bae et al., 2003). In Portland land values increased significantly when the construction of the MAX LRT system was announced (Knaap, Ding, \& Hopkins, 2001), and they increased even more after the system had been implemented (Chen et al., 1998). 
In addition to the projects mentioned in Tables 2-4 there are many other examples of projects where a general significant tendency of decreasing real estate prices can be observed when the distance to the nearest station increases. However, this tendency is not found for all distances. In particular, several studies found a direct negative effect within a very short distance from the station (Brandt \& Maennig, 2011; Chen et al., 1998; Debrezion, Pels, \& Rietveld, 2006; Landis et al., 1994). This was explained by increased noise annoyances and, to some extent, higher crime rates. In Phoenix this relationship was analysed explicitly since shorter distances to light rail stations resulted in higher real estate prices, whereas shorter distances to the light rail alignment resulted in lower real estate prices (Golub et al., 2012). Similarly, in Houston close proximity to LRT stations had significant negative impacts on property values whereas positive effects were seen for properties located longer away from stations (Pan, 2012). In Chen et al. (1998) the relative influence of the negative nuisance effects and the positive improved accessibility effects for the Portland MAX LRT system was compared. It was found that the improved accessibility outweighed the nuisance effects, but the study highlighted the importance of taking into account the nuisance effects which vary depending on the type of public transport system.

Such effects have also been observed for BRT systems. In Guangzhou real estate prices within 1,000 $\mathrm{m}$ from the BRT stations decreased whereas they increased for properties more than $1,000 \mathrm{~m}$ away from the stations. This tendency was not found for metro stations and was to a large extent due to noise annoyances and congestion problems (Salon et al., 2014). However, for the TransMilenio in Bogotá such an effect was not found (Munoz-Raskin, 2010). Here higher real estate prices were observed within a distance of $250 \mathrm{~m}$ from a BRT station than in a 250-500 $\mathrm{m}$ band around the stations.

Several of the examined BRT systems have shown to have a relatively large impact on property values with increases of up to 20-30\% in Brisbane in Australia. This large increase followed a significant upgrade where a completely segregated bus lane was established in a corridor from the city centre to the university southeast of the city which resulted in a reduction of the travel time by more than 30\% (Currie, 2006a). In the time following the opening of the system real estate prices in the corridor rose 2-3 times faster than those of similar properties, and the prices of residential properties within walking distance from the bus corridor were $20 \%$ higher after the opening than those of other comparable properties (Levinson, Zimmerman, Clinger, \& Gast, 2003). Bogotá also saw an increase of $13-15 \%$ for residential properties situated within 1,000 $\mathrm{m}$ of the TransMilenio system after the opening of an extension of the network (Rodríguez \& Mojica, 2009). A minor effect was observed in Seoul where the price of residential properties within $300 \mathrm{~m}$ from the new BRT line rose by $5-10 \%$ after the opening of the line (Cervero \& Kang, 2011). According to the same study the price of commercial properties within $150 \mathrm{~m}$ from a station rose by up to 26\%. In Pittsburgh (V. Perk et al., 2010) found that the East Busway BRT had a significant positive effect on real estate prices, and the effect of being close to a BRT station was bigger than that of being close to an LRT station. 
Other studies have compared the effects of BRT, LRT and metro, respectively. Debrezion, Pels, \& Rietveld (2007) concluded that real estate prices of properties situated within $400 \mathrm{~m}$ from socalled commuter rail stations were $14.1 \%$ higher, based on a comparison of 73 local public transport systems. However, no significant differences were found for properties situated close to LRT and BRT stations. In addition, the same study found that the effect on real estate prices was bigger for commercial properties than for residential properties when the property was situated within $400 \mathrm{~m}$ from a station. On the other hand, the effect was higher for residential properties situated more than $400 \mathrm{~m}$ from the station. In Beijing the effects of the newly established BRT line, Line 1, were compared with the effects of the metro (Ma et al., 2014). Here it was found that real estate prices were $5 \%$ higher for properties close to metro stations (within $800 \mathrm{~m}$ ), whereas no significant effect for properties situated close to BRT stations could be found. However, Deng \& Nelson (2013) report that the BRT line had positive effects on property development including rising property values along its corridor. This was based on a survey distributed to real-estate agents. In Guangzhou a minor effect for properties situated close to BRT stations could be observed, but it was not nearly as big as the effect observed for properties near the metro (Salon et al., 2014). This could be both be because the metro was more attractive, and also because the station areas around the metro had more attractive shops and were perceived as being less influenced by externalities, e.g. noise and congestion. Generally, the largest effects were found for the lines providing the biggest travel time benefits.

There is also a tendency that the effect was biggest in low-income areas whereas high-income areas did not experience the same increase in property values (Salon et al., 2014). This was probably because the inhabitants of these areas did not use public transport to the same extent as the lowincome groups where car ownership was generally lower. This, however, was not unequivocal as the opposite effect could be observed in Buffalo, USA (Hess and Almeida, 2007). Here the high-income areas experienced a positive effect from the light rail system whereas the low-income areas experienced a negative effect.

A number of studies found decreasing real estate prices after the implementation of rail systems. In Manchester the proximity effect was $-6 \%$ which was probably due to an average distance to stations within the entire area of analysis of only $1.36 \mathrm{~km}$. Hence, many residents already had access to stations (Forrest et al., 1996). Similarly, a decrease of 7\% was found in San Diego which was explained by a very low ridership in a corridor with generally very high average incomes. Thus, the residents in the corridor did not find the system attractive (Cervero \& Duncan, 2002b). In Atlanta, up to $19 \%$ lower real estate prices were found within $400 \mathrm{~m}$ of MARTA stations. On the other hand, the prices were highest in a 1-3 mile band around the stations, probably because the negative externalities in the form of noise and crime close to the stations had a higher impact than the attractiveness of the system (Bowes \& Ihlanfeldt, 2001).

An overview of the magnitudes of impacts on property values of BRT, LRT and metros is shown as a histogram in Figure 2. Note, however, that the graph only shows selected results from Tables 2-4 since many studies only concluded whether or not a significant effect could be observed. 
As a consequence, the histogram only includes 41 of the 86 systems reviewed. Furthermore, as mentioned many big differences generally exist between the projects. A conclusion based directly on the histogram would imply a significant degree of uncertainty.

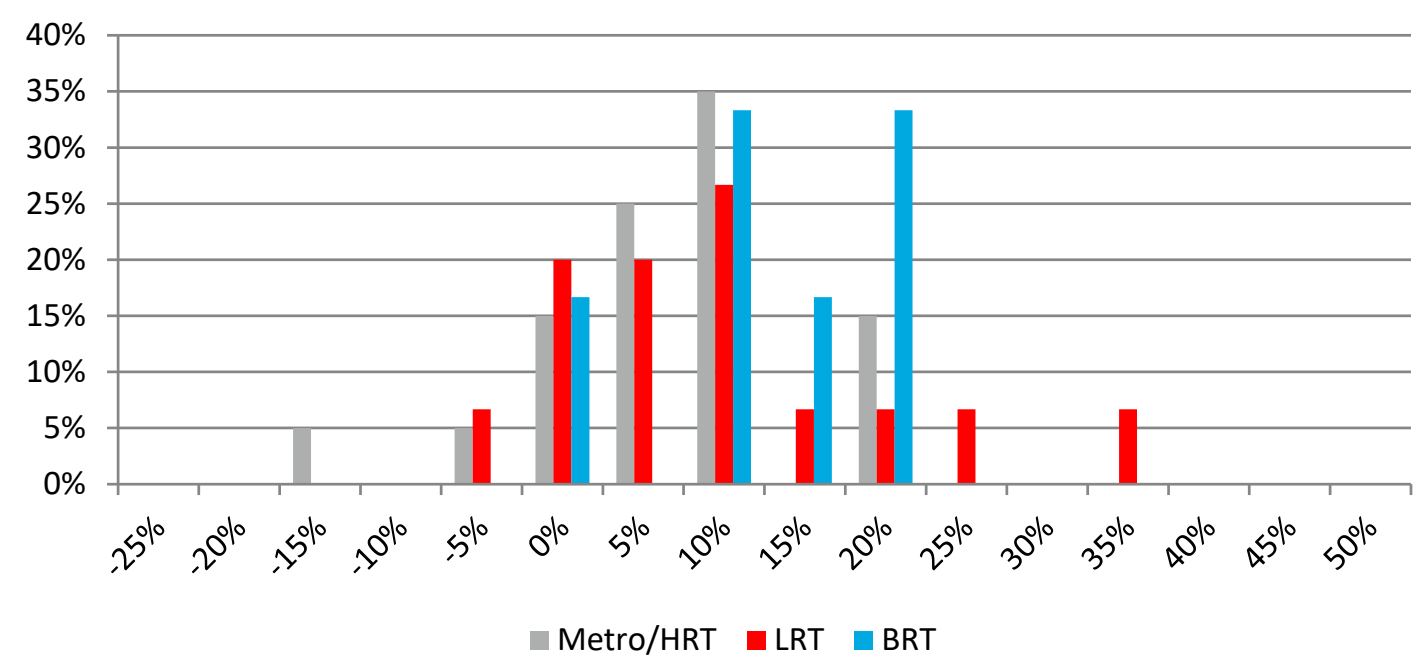

Figure 2: Change in property values after implementation of public transport systems.

The distributions of the changes in property values were tested using two-sample t-tests across the three modes, i.e. BRT, LRT, and metro/heavy rail. The three subsamples showed no significant differences between variances, hence the pooled test statistic was preferred.

\begin{tabular}{|lccc|}
\hline \multicolumn{1}{|c}{ System } & DF & t value & $\operatorname{Pr}>|\mathbf{t}|$ \\
\hline Metro vs. LRT & 33 & 0.89 & 0.3811 \\
\hline Metro vs. BRT & 24 & 1.41 & 0.1719 \\
\hline LRT vs. BRT & 19 & 0.61 & 0.5509 \\
\hline
\end{tabular}

Table 5: Statistical t-tests of the difference in means of property value effects across public transport modes.

Generally, the results showed no significant differences across the three modes, i.e. significant strategic effects in terms of increases in property values were not limited to rail-based public transport systems, cf. Table 5. Projects that resulted in big increases in property values, as well as projects with less or no influence, were found across all three modes. Based on the subsample of projects in this study there seems to be a more certain difference between BRT and metro/heavy rail projects ( $83 \%$ confidence level) whereas the least certain difference is seen when comparing LRT and BRT (45\% confidence level). Hence, the present study finds the largest effects for BRT systems and the lowest effects for metro/heavy rail, cf. Figure 2. However, the effects for all systems are significantly positive, and not significantly different from each other. Hence, based on these simple key figures it is not possible to draw any general conclusions about the influence of each of the three transport systems on the real estate market. Instead, the findings suggest that effects are rather due to other reasons than the choice of type of system. Most importantly, large effects were observed when notable improvements were implemented. In addition, negative effects were seen close to station areas due to externalities which highlights the importance of creating attractive station areas when implementing public transport systems. Thorough implementation is thus important in ensuring positive effects on property values. 


\section{Urban development}

As could be seen in the previous section, increases in real estate prices are not exclusively associated with rail-based public transport systems. It should therefore be possible to obtain urban development effects in relation to BRT. However, there are not many examples of urban development in connection with BRT in Europe and Asia reported in the literature (Cervero, 2013; Deng \& Nelson, 2011). Several studies argue that some of the reasons for this are the lack of permanence (Dittmar \& Ohland, 2004; Parker, McKeever, Arrington, \& Smith-Heimer, 2002; Rodríguez \& Targa, 2004) and lack of newness (Parker et al., 2002) of bus-based systems as compared to rail-based systems. However, a review of possible reasons in (Currie, 2006b) showed that the largest weaknesses were related to weak industry capabilities regarding bus-based transit-oriented development (TOD), the lack of a positive track record for already implemented systems and the availability of park-and-ride facilities as they limit TOD opportunities (Currie, 2006a). In (Kamruzzaman, Baker, Washington, \& Turrell, 2014) a comparison of different types of TOD in Brisbane was conducted which confirmed well-known effects of increased transit ridership and the use of active travel modes for people living in TODs. These results were found for both bus-based and rail-based TOD, hence suggesting that effects are not mode-specific, but rather a result of coherent planning.

The best examples of urban development in corridors served by buses are probably Curitiba and Ottawa (Currie, 2006b). In Curitiba, the BRT system became a big success, since $45 \%$ of the longer trips which were not made by foot or bicycle, were made by the BRT system (Cervero \& Dai, 2014). The urban development was assured by means of planning laws that dictated that urban development should take place along the BRT corridors (Cervero, 1998). Hence, the system was not only implemented as a tool to improve the traffic situation in the city, but rather also as an instrument to form the urban development in a more sustainable direction. In Ottawa, a significant urban development was also seen in connection with the implementation of the BRT system Transitway. Due to the big success of the system, the urban development was concentrated along the bus lines, and the largest economic effect was precisely the urban development which was assessed to be worth about $\$ 675$ million (Levinson, Zimmerman, Clinger, Rutherford, et al., 2003). Almost the same high investment level was obtained as a result of the BRT line in Pittsburgh where renovations and new constructions worth about $\$ 302$ million were carried out in connection with the stations along the East Busway (Levinson, Zimmerman, Clinger, \& Gast, 2003). Similar trends were seen in Boston where properties near the BRT line were densified after the implementation of the Silver Line BRT. The properties were to a great extent converted into apartment buildings. The total amount of money put into the urban development reached more than $\$ 600$ million (V. A. Perk, Catala, \& Reader, 2012). Even larger effects were observed along the Euclid Corridor transportation project in Cleveland totalling \$4.3 billion in real-estate developments (Weinstock et al., 2011). The Orange Line in Los Angeles also gave rise to urban development near the stations due to the significantly improved travel time and the generally high attractiveness of the system after the opening (Callaghan \& Vincent, 
2007). Furthermore, a certain urban development was obtained in connection with the BRT line in Seoul (Cervero \& Kang, 2011). Here the areas around the BRT stations were developed, and a densification of the dwellings from one-family houses to flats was seen. It was assessed that notably improved travel times and regularity were more important parameters for a potential urban development than the type of system which was implemented. This suggested that urban developments could be obtained by both BRT and rail-based systems if urban development was integrated into the planning of station areas as early as possible in the planning process (Levinson et al., 2002).

Other BRT systems did not obtain the same effects. In Adelaide, no evidence of increased urban development was seen in relation to the O-Bahn system (Currie, 2006a). One important reason was that more than $50 \%$ of boarding passengers used car as access mode hence requiring large parkand-ride facilities at station areas which restricts the urban development potential (Dittmar \& Ohland, 2004). Similarly, in Ahmedabad in India and Bogotá in Columbia no significant effect on urban development was observed despite the fact that TransMilenio in Bogotá is one the world's most advanced BRT with a large extension and high ridership (Cervero \& Dai, 2014). For these two cities the main reason was assessed to be bad station conditions. During the construction phase focus was on creating a cost-effective and fast system which was out of tune with the development of the station areas. Many stations were placed in the middle of large roads to ensure the highest possible travel speed at the lowest possible price. This resulted in bad accessibility for pedestrians and unattractive station areas. This is underpinned by other analyses from Bogotá which showed that attributes such as pavements and zebra crossings were highly valued by the passengers of the system. Hence, stations with easy access had significantly more passengers than other stations (Estupiñán \& Rodríguez, 2008). Furthermore, Cervero et al. (2004) emphasised that good pedestrian access is crucial for ensuring succesfull TOD. It is therefore important to bear these considerations in mind during the planning phase of public transport projects. This is especially important for BRT systems where the challenge with respect to creating the potential for urban development at stations is bigger than for metros which do not create externalities at the surface level due to them being underground systems.

\section{Discussion}

While the current study provides a thorough review of the existing literature and compares the effects of various modes of public transport, the data source used in this study is not without limitations.

Firstly, the study compiled a large sample of 86 public transport systems. Though it is comprehensive and of a sufficient size to not being random data, it is not complete as it for obvious reasons does not include all systems ever implemented. Neither is it fully representative in terms of systems from specific countries, city sizes, etc. Hence, future work could focus on investigating the impacts from transit systems as a function of local economic or demographic characteristics as well as 
the actual level of service improvements, effects on ridership, changes in mode choice and property values.

Secondly, the data were collected from numerous different sources which applied different methodologies hence giving rise to lacking consistency. For studies on traffic impacts the reported improvements were measured at different time points after completion or implementation of the systems. Hence, ridership increases and modal shifts were not directly comparable between studies. The systems included in this study all reported effects obtained after up to 3-4 years after completion in order to reduce the effect of general traffic growth or other factors. Some studies were deliberately not included as they reported effects after up to 10 years after completion.

The inconsistency also applied to the studies on property values. As previously mentioned different definitions of station proximity were used, but studies also used different methodological approaches when estimating the station proximity impact. Most studies used the hedonic pricing method, but studies differed in estimation methods with only some studies taking into account spatial autocorrelation, e.g. Rodríguez \& Targa (2004). Other studies reported changes in property values based on comparisons with control group areas, e.g. V. Perk \& Catalá (2009), Salon et al. (2014), Weinstein \& Clower (2002), and others.

For the urban development effects no consistent definition exists of what impacts to include among urban regeneration, development projects, TOD or densification of existing properties. Hence, the present paper summarises findings from numerous papers on this topic with the purpose of highlighting possible effects rather than creating specific comparisons between transport modes. Further research could investigate the link between urban development effects and the public transport systems in more detail, including the most important elements contributing to an improved level of service and urban development, a research area also highlighted by other studies, e.g. in Stokenberga (2014).

Thirdly, this paper operates with a division into three groups of transit systems, namely BRT, LRT and metro/commuter rail systems. While many systems are easily classified, others are more difficult to classify. This is especially the case for many improved bus systems incorporating scattered bus lanes and single ITS features. However, in order to being able to analyse strategic effects this paper has only included BRT systems that are notably upgraded from conventional bus lines in terms of (almost) fully segregated infrastructure and multiple ITS elements. Similar definition challenges exist for rail lines. For example the Metrolink network in Manchester was upgraded from an existing suburban, heavy rail system into a LRT system by adding newly constructed lines on city centre streets with stations in the downtown area (Forrest et al., 1996; Knowles, 1996). Hence, parts of the system could be categorised as commuter rail even after the transformation of the network. In the present paper this system was categorised as LRT. The LRT systems included vary with regards to the degree of segregation from other traffic, as many otherwise successful LRT systems are mixed with car traffic, especially in narrow city centre street networks. The last group of systems include commuter rail and metro systems which are characterised by being heavy rail systems running at 
higher speeds with longer stop spacings. The final division into three groups was a compromise between creating as few groups as possible while at the same time ensuring their homogenity. Hence, a division into more groups could be reasonable; for example by further dividing BRT systems based on the BRT level as suggested by Wright \& Hook (2007), splitting LRT and traditional tram systems, possibly taking into account the degree of segregation from other traffic, or creating independent groups for heavy rail dependent on whether they are underground or overground systems or dependent on train type used, e.g. large regional trains or small metro trains. However, a further division of systems would reduce the sample size for each system.

Lastly, this study did not focus on whether effects on property values are in fact generative. Several sources question this suggesting that effects are rather distributive (Handy, 2005). By this, the positive effects should not be seen as pure growth, but rather as a redistribution of growth in the area close to the new public transport system which is outweighed by the decreasing property values in other areas (Giuliano, 2004). However, even if impacts are redistributive, Cervero (2009) suggests that a total positive effect is realised because of the agglomeration effects occurring from the spatial redistribution, thus creating generative economic growth. Further research should investigate this aspect in greater detail in order to draw conclusions on this aspect.

\section{Conclusions}

This present paper showed that large effects on travel time can occur by implementing BRT and lead to significant modal shifts similar to those found when implementing rail-based public transport systems such as LRT and metro. In addition, the review of 86 public transport systems showed that significant positive impacts on property values can be obtained by investing in public transport systems independent of system choice, i.e. BRT, LRT or metro/heavy rail. For the 41 projects which were analysed statistically in this study no significant differences between system choices were found, but BRT systems seemed to show the largest effects. The results suggested that the impacts depend more on the extent to which the system improves the existing situation, the competition with car traffic and how the system is implemented in the local context.

For BRT systems, notable improvements with respect to travel times compared to the basis situation are needed in order for people to consider the system as being more attractive than ordinary bus lines. This also includes measures to improve the overall travel time, e.g. service frequency, and comfort, e.g. guidance. Furthermore, it is important to ensure good accessibility to the station areas to obtain positive strategic effects in the form of urban development and increased property values. However, it can be difficult to combine short travel times and improved urban spaces, as high-class BRT systems take up large areas at the surface level as compared to underground metro systems. The largest travel time reductions and increases in ridership were thus seen in cities where the BRT line was segregated from other traffic, for instance in the middle of a large road, and where operations were frequent thus reducing waiting times. Such system designs make it difficult to create attractive 
urban spaces around BRT stations due to the significant intervention in the urban space as compared to the establishment of for instance sub-surface metro systems. This was confirmed by several analyses that showed decreasing real estate prices in the immediate vicinity of BRT stations as the benefits from the increased mobility did not compensate for the negative externalities, e.g. noise and barrier effects. To create successful BRT systems it is thus essential to consider how to obtain large benefits in the form of travel time and improved accessibility while at the same time creating an attractive and accessible environment around the stations.

\section{References}

Adair, A., McGreal, S., Smyth, A., Cooper, J., \& Ryley, T. (2000). House Prices and Accessibility: The Testing of Relationships within the Belfast Urban Area. Housing Studies, 15(5), 699-716. http://doi.org/10.1080/02673030050134565

Al-Dubiki, S., \& Mees, P. (2010). Bus rapid transit in Ottawa, 1978 to 2008: Assessing the results. The Town Planning Review, 81(4), 407-424. Retrieved from http://search.proquest.com.globalproxy.cvt.dk/openview/0285da896d058b94d84a43607a610313 $/ 1$ ?pq-origsite $=$ gscholar

Al-Mosaind, M. A., Dueker, K. J., \& Strathman, J. G. (1993). Light-Rail Transit Stations and Property Values: A Hedonic Price Approach. Transportation Research Record, (1400). Retrieved from http://trid.trb.org/view.aspx?id=383269

Alpkokin, P., \& Ergun, M. (2012). Istanbul Metrobüs: first intercontinental bus rapid transit. Journal of Transport Geography, 24, 58-66. http://doi.org/10.1016/j.jtrangeo.2012.05.009

Armstrong, J., \& Robert, J. (1994). Impacts of Commuter Rail Service as Reflected in Single-Family Residential Property Values. Transportation Research Record, (1466), 88-98. Retrieved from http://trid.trb.org/view.aspx?id=425326

Armstrong, R. J., \& Rodríguez, D. A. (2006). An Evaluation of the Accessibility Benefits of Commuter Rail in Eastern Massachusetts using Spatial Hedonic Price Functions.

Transportation, 33(1), 21-43. http://doi.org/10.1007/s11116-005-0949-x

ATISREAL, Geofutures, UCL, \& Group, S. (2004). Land Value and Public Transport - Stage Two: Testing the Methodology on the Croydon Tramlink. London, UK: Royal Institute of Chartered Surveyors.

Bae, C.-H. C., Jun, M.-J., \& Park, H. (2003). The impact of Seoul's subway Line 5 on residential property values. Transport Policy, 10(2), 85-94. http://doi.org/10.1016/S0967-070X(02)00048-3

Banister, D., \& Thurstain-Goodwin, M. (2011). Quantification of the non-transport benefits resulting from rail investment. Journal of Transport Geography, 19(2), 212-223. http://doi.org/10.1016/j.jtrangeo.2010.05.001

Bollinger, C. R., \& Ihlanfeldt, K. R. (1997). The Impact of Rapid Rail Transit on Economic Development: The Case of Atlanta's MARTA. Journal of Urban Economics, 42(2), 179-204. 
http://doi.org/10.1006/juec.1996.2020

Bottoms, G. D. (2003). Continuing developments in light rail transit in western Europe. In Proceedings of the 9th National Light Rail Transit Conference (pp. 713-728).

Bowes, D., \& Ihlanfeldt, K. R. (2001). Identifying the Impacts of Rail Transit Stations on Residential Property Values. Journal of Urban Economics, 50, 1-25. Retrieved from http://ac.elscdn.com.globalproxy.cvt.dk/S0094119001922144/1-s2.0-S0094119001922144main.pdf?_tid=2988b1f4-a88b-11e5-94f500000aacb35f\&acdnat=1450775315_949878c0af3e5faff74acfcf8da8a980

Brandt, S., \& Maennig, W. (2011). The impact of rail access on condominium prices in Hamburg. Transportation, 39(5), 997-1017. http://doi.org/10.1007/s11116-011-9379-0

Cain, A., Flynn, J., McCourt, M., \& Reyes, T. (2009). Quantifying the Importance of Image and Perception to Bus Rapid Transit. Retrieved from http://trid.trb.org/view.aspx?id=889573

Callaghan, L., \& Vincent, W. (2007). Preliminary Evaluation of Metro Orange Line Bus Rapid Transit Project. Transportation Research Record: Journal of the Transportation Research Board, 2034, 37-44. http://doi.org/10.3141/2034-05

Cao, X. (Jason), \& Schoner, J. (2014). The influence of light rail transit on transit use: An exploration of station area residents along the Hiawatha line in Minneapolis. Transportation Research Part A: Policy and Practice, 59, 134-143.

Cervero, R. (1984). Journal Report: Light Rail Transit and Urban Development. Journal of the American Planning Association, 50(2), 133-147. http://doi.org/10.1080/01944368408977170

Cervero, R. (1998). The Transit Metropolis: A Global Inquiry. Retrieved from https://books.google.com/books?hl=da\&lr=\&id=rpUhiJlbHHkC\&pgis=1

Cervero, R. (2009). Urban Development on Railway-Served Land: Lessons and Opportunities for the Developing World.

Cervero, R. (2013). Bus Rapid Transit (BRT): An Efficient and Competitive Mode of Public Transport. IURD Working Paper 2013-01. Retrieved from http://escholarship.org/uc/item/4sn2f5wc

Cervero, R., \& Dai, D. (2014). BRT TOD: Leveraging transit oriented development with bus rapid transit investments. Transport Policy, 36, 127-138. http://doi.org/10.1016/j.tranpol.2014.08.001

Cervero, R., \& Duncan, M. (2002a). Land value impacts of rail transit services in Los Angeles County.

Cervero, R., \& Duncan, M. (2002b). Land value impacts of rail transit services in San Diego County.

Cervero, R., \& Kang, C. D. (2011). Bus rapid transit impacts on land uses and land values in Seoul, Korea. Transport Policy, 18(1), 102-116. http://doi.org/10.1016/j.tranpol.2010.06.005

Cervero, R., Murphy, S., Ferrell, C., Goguts, N., Tsai, Y.-H., Arrington, G. B., ... Witenstein, N. (2004). Transit-Oriented Development in the United States: Experiences, Challenges, and Prospectes.

Chen, H., Rufolo, A., \& Dueker, K. (1998). Measuring the Impact of Light Rail Systems on Single- 
Family Home Values: A Hedonic Approach with Geographic Information System Application. Transportation Research Record: Journal of the Transportation Research Board, 1617, 38-43. Retrieved from http://trrjournalonline.trb.org.globalproxy.cvt.dk/doi/abs/10.3141/1617-05 City and County of Honolulu. (2001). Honolulu, Hawaii Brief: Bus Rapid Transit Project. Honolulu, Hawaii Brief: Bus Rapid Transit Project. Honolulu.

Copley, G., Thomas, M., Maunsell, F., \& Georgeson, N. (2002). Croydon Tramlink Impact Study. In European Transport Conference. Retrieved from http://trid.trb.org/view.aspx?id=803501

Currie, G. (2006a). Bus Rapid Transit in Australasia: Performance, Lessons Learned and Futures. Journal of Public Transportation, 9(3), 1-22. http://doi.org/10.5038/2375-0901.9.3.1

Currie, G. (2006b). Bus Transit Oriented Development - Strengths and Challenges Relative to Rail. Journal of Public Transportation, 9(4), 1-21. http://doi.org/10.5038/2375-0901.9.4.1

Currie, G., Ahern, A., \& Delbosc, A. (2011). Exploring the drivers of light rail ridership: An empirical route level analysis of selected Australian, North American and European systems.

Transportation, 38(3), 545-560. http://doi.org/10.1007/s11116-010-9314-9

Currie, G., \& Delbosc, A. (2011). Understanding bus rapid transit route ridership drivers: An empirical study of Australian BRT systems. Transport Policy, 18(5), 755-764. http://doi.org/10.1016/j.tranpol.2011.03.003

Currie, G., \& Delbosc, A. (2013). Exploring Comparative Ridership Drivers of Bus Rapid Transit and Light Rail Transit Routes. Journal of Public Transportation, 16(2), 47-65. http://doi.org/10.5038/2375-0901.16.2.3

Currie, G., \& Sarvi, M. (2012). New Model for Secondary Benefits of Transit Priority. Transportation Research Record: Journal of the Transportation Research Board, 2276(1), 63-71. http://doi.org/10.3141/2276-08

Dabinett, G., Gore, T., Haywood, R., \& Lawless, P. (1999). Transport investment and regeneration. Sheffield: 1992-1997. Transport Policy, 6(2), 123-134. http://doi.org/10.1016/S0967070X(99)00013-X

Darido, G. (2006). Bus rapid transit developments in China: Perspectives from research, meetings and site visits in April 2006. Washington, DC, USA. Retrieved from http://trb.metapress.com/openurl.asp?genre=article\&id=doi:10.3141/2193-03

Debrezion, G., Pels, E., \& Rietveld, P. (2006). The Impact of Rail Transport on Real Estate Prices: An Empirical Analysis of the Dutch Housing Market. Tinbergen Institute. Retrieved from http://econpapers.repec.org/RePEc:tin:wpaper:20060031

Debrezion, G., Pels, E., \& Rietveld, P. (2007). The Impact of Railway Stations on Residential and Commercial Property Value: A Meta-analysis. The Journal of Real Estate Finance and Economics, 35(2), 161-180. http://doi.org/10.1007/s11146-007-9032-z

Deng, T., \& Nelson, J. D. (2011). Recent Developments in Bus Rapid Transit: A Review of the Literature. Transport Reviews, 31(1), 69-96. http://doi.org/10.1080/01441647.2010.492455

Deng, T., \& Nelson, J. D. (2013). Bus Rapid Transit implementation in Beijing: An evaluation of 
performance and impacts. Research in Transportation Economics, 39(1), 108-113. http://doi.org/10.1016/j.retrec.2012.06.002

Dittmar, H., \& Ohland, G. (2004). The new transit town : best practices in transit-oriented development. Island Press.

Dueker, K., \& Bianco, M. (1999). Light-Rail-Transit Impacts in Portland: The First Ten Years. Transportation Research Record: Journal of the Transportation Research Board, 1685, 171180. Retrieved from http://trijournalonline.trb.org.globalproxy.cvt.dk/doi/abs/10.3141/1685-22

Ernst, J. (2005). Initiating Bus Rapid Transit in Jakarta, Indonesia. Transportation Research Record: Journal of the Transportation Research Board, 1903, 20-26. http://doi.org/10.3141/1903-03

Estupiñán, N., \& Rodríguez, D. A. (2008). The relationship between urban form and station boardings for Bogotá's BRT. Transportation Research Part A: Policy and Practice, 42(2), 296-306. http://doi.org/10.1016/j.tra.2007.10.006

Finn, B., Heddebaut, O., Kerkhof, A., Rambaud, F., Lozano, O. S., \& Soulas, C. (2011). Buses with high level of service - Fundamental characteristics and recommendations for decision-making and research.

Forrest, D., Glen, J., \& Ward, R. (1996). The Impact of a Light Rail System on the Structure of House Prices: A Hedonic Longitudinal Study. Journal of Transport Economics and Policy, 30(1), 1529. Retrieved from http://www.jstor.org.globalproxy.cvt.dk/stable/20053094?seq=1\#page_scan_tab_contents

Fredriksen, K. M. R. (2013). Bybanens innvirkning på boligpriser i Bergen. Universitetet i Agder. Retrieved from http://brage.bibsys.no/xmlui/bitstream/handle/11250/194166/BE-501 2013 h\%C3\%B8st masteroppgave Kajsa Martine Roaldsdatter Fredriksen.pdf?sequence=1\&isAllowed=y

Gatzlaff, D. H., \& Smith, M. T. (1993). The Impact of the Miami Metrorail on the Value of Residences near Station Locations. Land Economics, 69(1), 54-66. Retrieved from http://www.jstor.org.globalproxy.cvt.dk/stable/3146278?seq=1\#page_scan_tab_contents

Giuliano, G. (2004). Land Use Impacts of Transportation Investments: Highway and Transit. In G. Giuliano \& S. Hanson (Eds.), The Geography of Urban Transportation (3rd ed., pp. 237-273). Washington, DC, USA: Guilford Press.

Global BRT Data. (2016). Retrieved March 7, 2016, from www.brtdata.org

Golub, A., Guhathakurta, S., \& Sollapuram, B. (2012). Spatial and Temporal Capitalization Effects of Light Rail in Phoenix: From Conception, Planning, and Construction to Operation. Journal of Planning Education and Research, 32(4), 415-429. http://doi.org/10.1177/0739456X12455523

Hack, J. (2002). Regeneraton and Spatial Development: a Review of Research and Current Practice. Toronto.

Handy, S. (2005). Smart Growth and the Transportation-Land Use Connection: What Does the Research Tell Us? International Regional Science Review, 28(2), 146-167. http://doi.org/10.1177/0160017604273626 
Harper, R., \& Bird, J. (2000). Midland Metro: Monitoring the Impacts. In European Transport Conference. Retrieved from http://trid.trb.org/view.aspx?id=674817

Hass-Klau, C., Crampton, G., Biereth, C., \& Deutsch, V. (2003). Bus or Light Rail: Making the Right Choice: A Financial, Operational, and Demand Comparison of Light Rail, Guided Busways and Bus Lanes (Second Ed.). Brighton, UK: Environmental \& Transport Planning.

Heddebaut, O., Finn, B., Rabuel, S., \& Rambaud, F. (2010). The European Bus with a High Level of Service (BHLS): Concept and Practice. Built Environment, 36(3), 307-316. http://doi.org/10.2148/benv.36.3.307

Hensher, D. A., \& Golob, T. F. (2008). Bus rapid transit systems: a comparative assessment. Transportation, 35(4), 501-518. http://doi.org/10.1007/s11116-008-9163-y

Hess, D. B., \& Almeida, T. M. (2007). Impact of Proximity to Light Rail Rapid Transit on Stationarea Property Values in Buffalo, New York. Urban Studies, 44(5), 1041-1068. Retrieved from http://usj.sagepub.com.globalproxy.cvt.dk/content/44/5-6/1041.full.pdf

Hidalgo, D., \& Muñoz, J. C. (2014). A review of technological improvements in bus rapid transit (BRT) and buses with high level of service (BHLS). Public Transport, 6(3), 185-213. http://doi.org/10.1007/s12469-014-0089-9

Hoffman, A. (2008). Advanced Network Planning for Bus Rapid Transit: The "Quickway" Model as a Modal Alternative to "Light Rail Lite." Washington, DC, USA. Retrieved from http://trid.trb.org/view.aspx?id=851316

Ingvardson, J. B., Jensen, J. K., \& Nielsen, O. A. (2015). Mesoscopic modelling of on-street public transport. Proceedings of CASPT 2015 Conference.

Jones, P., Eyers, T., Bray, J., Georgeson, N., Powell, T., Paris, J., \& Lane, R. (2004). The Jubilee Line Extension impact study: Main findings and lessons learnt.

Kamruzzaman, M., Baker, D., Washington, S., \& Turrell, G. (2014). Advance transit oriented development typology: Case study in brisbane, australia. Journal of Transport Geography, 34, 54-70. http://doi.org/10.1016/j.jtrangeo.2013.11.002

Knaap, G. J., Ding, C., \& Hopkins, L. D. (2001). Do Plans Matter? The Effects of Light Rail Plans on. Journal of Planning Education and Research, 21(1), 32-39. http://doi.org/10.1177/0739456X0102100103

Knowles, R. D. (1996). Transport impacts of greater Manchester's metrolink light rail system. Journal of Transport Geography, 4(1), 1-14. http://doi.org/10.1016/0966-6923(95)00034-8

Knowles, R. D., \& Ferbrache, F. (2015). Evaluation of wider economic impacts of light rail investment on cities. Journal of Transport Geography. http://doi.org/10.1016/j.jtrangeo.2015.09.002

Kolstrup, K. (2006). A Hedonic Price Study of the Copenhagen Metro. The University of Leeds. Landis, J., Guhathakurta, S., Huang, W., Zhang, M., \& Fukuji, B. (1995). Rail Transit Investments, Real Estate Values, and Land Use Change: A Comparative Analysis of Five California Rail Transit Systems. Retrieved from http://escholarship.org/uc/item/4hh7f652 
Landis, J., Zhang, M., \& Guhathakurta, S. (1994). Capitalization of Transit Investments into SingleFamily Home Prices: A Comparative Analysis of Five California Rail Transit Systems. Berkeley, California, USA. Retrieved from http://www.uctc.net/research/papers/769.pdf

Lee, S. S., \& Senior, M. L. (2013). Do light rail services discourage car ownership and use? Evidence from Census data for four English cities. Journal of Transport Geography, 29, 11-23. http://doi.org/10.1016/j.jtrangeo.2012.12.002

Levinson, H., Zimmerman, S., Clinger, J., \& Gast, J. (2003). Bus Rapid Transit: Synthesis of Case Studies. Transportation Research Record: Journal of the Transportation Research Board, 1841, 1-11. http://doi.org/10.3141/1841-01

Levinson, H., Zimmerman, S., Clinger, J., \& Rutherford, G. (2002). Bus Rapid Transit: An Overview. Journal of Public Transportation, 5(2), 1-30. http://doi.org/10.5038/2375-0901.5.2.1

Levinson, H., Zimmerman, S., Clinger, J., Rutherford, S., Smith, R., Cracknell, J., \& Soberman, R. (2003). Bus Rapid Transit, Volume 1: Case Studies in Bus Rapid Transit. World Transit Research. Retrieved from http://www.worldtransitresearch.info/research/3042

Lin, J. (2002). Gentrification and Transit in Northwest Chicago. Journal of the Transportation Research Forum, 56(4). Retrieved from http://trid.trb.org/view.aspx?id=728134

Ma, L., Ye, R., \& Titheridge, H. (2014). Capitalization Effects of Rail Transit and Bus Rapid Transit on Residential Property Values in a Booming Economy. Transportation Research Record: Journal of the Transportation Research Board, 2451, 139-148. http://doi.org/10.3141/2451-16

Martínez, L., \& Viegas, J. (2009). Effects of Transportation Accessibility on Residential Property Values. Transportation Research Record: Journal of the Transportation Research Board, 2115, 127-137. http://doi.org/10.3141/2115-16

McDonald, J. F., \& Osuji, C. I. (1995). The effect of anticipated transportation improvement on residential land values. Regional Science and Urban Economics, 25(3), 261-278. http://doi.org/10.1016/0166-0462(94)02085-U

Munoz-Raskin, R. (2010). Walking accessibility to bus rapid transit: Does it affect property values? The case of Bogotá, Colombia. Transport Policy, 17(2), 72-84. http://doi.org/10.1016/j.tranpol.2009.11.002

National BRT Institute. (2003). South Miami-Dade Busway System Summary. University of South Florida, Tampa.

Nikitas, A., \& Karlsson, M. (2015). A Worldwide State-of-the-Art Analysis for Bus Rapid Transit: Looking for the Success Formula. Journal of Public Transportation, 18(1), 1-33. http://doi.org/10.5038/2375-0901.18.1.3

O’Mahony, M. (2002). Quality bus corridors in Dublin. Transportation Research Record, (1791), 121-126. http://doi.org/10.3141/1791-18

Olesen, M. (2014). Making Light Rail Mobilities. Aalborg University. Retrieved from http://vbn.aau.dk/files/196654311/Olesen_2014_Making_Light_Rail_Mobilities.pdf

Pagliara, F., \& Papa, E. (2011). Urban rail systems investments: an analysis of the impacts on 
property values and residents' location. Journal of Transport Geography, 19(2), 200-211. http://doi.org/10.1016/j.jtrangeo.2010.02.006

Pan, Q. (2012). The impacts of an urban light rail system on residential property values: a case study of the Houston METRORail transit line. Transportation Planning and Technology, 36(2), 145169. http://doi.org/10.1080/03081060.2012.739311

Parker, T., McKeever, M., Arrington, G. B. B., \& Smith-Heimer, J. (2002). Statewide TransitOriented Development Study Factors for Success in California. California Department of Transportation.

Perdomo Calvo, J. A., Mendoza, C. A., Baquero-Ruiz, A. F., \& Mendieta-Lopez, J. C. (2007). Study of the Effect of the Transmilenio Mass Transit Project on the Value of Properties in Bogotá, Colombia. Lincoln Institute of Land Policy. Retrieved from http://papers.ssrn.com/abstract=1586381

Perk, V. A., Catala, M., \& Reader, S. (2012). Land Use Impacts of Bus Rapid Transit: Phase IIEffects of BRT Station Proximity on Property Values along the Boston Silver Line Washington Street Corridor. Washington, DC, USA. Retrieved from http://trid.trb.org/view.aspx?id=1248174

Perk, V., \& Catalá, M. (2009). Land Use Impacts of Bus Rapid Transit: Effects of BRT Station Proximity on Property Values along the Pittsburgh Martin Luther King, Jr. East Busway. Retrieved from http://www.nbrti.org/docs/pdf/Property Value Impacts of BRT_NBRTI.pdf

Perk, V., Mugharbel, M., \& Catalá, M. (2010). Impacts of Bus Rapid Transit Stations on Surrounding Single-Family Home Values. Transportation Research Record: Journal of the Transportation Research Board, 2144, 72-79. http://doi.org/10.3141/2144-09

Pickett, M. W. (1984). The Effect of the Tyne and Wear Metro on Residential Property Values. Supplementary Report. Wokingham, Berkshire, UK. Retrieved from http://trid.trb.org/view.aspx?id=210757

Rabuel, S. (2010). Buses with a High Level of Services: Choosing and implementing the right system. Retrieved from http://www.nbrti.org/docs/pdf/buseshighlevelofservice_bhns_2009_english.pdf Richmond, J. (1991). Transport of Delight - The Mythical Conception of Rail Transit in Los Angeles. Massachusetts Institute of Technology. Retrieved from http://thetech.mit.edu/ richmond/publications/transportofdelightthesis.pdf

Rodríguez, D. A., \& Mojica, C. H. (2009). Capitalization of BRT network expansions effects into prices of non-expansion areas. Transportation Research Part A: Policy and Practice, 43(5), 560-571. http://doi.org/10.1016/j.tra.2009.02.003

Rodríguez, D. A., \& Targa, F. (2004). Value of accessibility to Bogotá's bus rapid transit system. Transport Reviews, 24(5), 587-610. http://doi.org/10.1080/0144164042000195081

Ryan, S. (1999). Property Values and Transportation Facilities: Finding the Transportation-Land Use Connection. Journal of Planning Literature, 13(4), 412-427. http://doi.org/10.1177/08854129922092487 
Salon, D., Wu, J. (Dora), \& Shewmake, S. (2014). Impact of Bus Rapid Transit and Metro Rail on Property Values in Guangzhou, China. Transportation Research Record: Journal of the Transportation Research Board, 2452, 36-45. http://doi.org/10.3141/2452-05

Stokenberga, A. (2014). Does Bus Rapid Transit Influence Urban Land Development and Property Values: A Review of the Literature. Transport Reviews, 34(3), 276-296. http://doi.org/10.1080/01441647.2014.902404

Suzuki, H., Cervero, R., \& Iuchi, K. (2013). Transforming Cities with Transit: Transit and Land-Use Integration for Sustainable Urban Development. Retrieved from https://books.google.com/books?hl=da\&lr=\&id=ukbdW6mH_0UC\&pgis=1

Voith, R. (1991). Is access to Center City still valuable? Business Review, 3-12. Retrieved from http://www.phil.frb.org/research-and-data/publications/business-review/1991/brja91rv.pdf

Voith, R. (1993). Changing Capitalization of CBD-Oriented Transportation Systems: Evidence from Philadelphia, 1970-1988. Journal of Urban Economics, 33(3), 361-376. http://doi.org/10.1006/juec.1993.1021

Vuk, G. (2005). Transport impacts of the Copenhagen Metro. Journal of Transport Geography, 13(3), 223-233. http://doi.org/10.1016/j.jtrangeo.2004.10.005

Weinstein, B. L., \& Clower, T. L. (2002, September 1). An Assessment of the DART LRT on Taxable Property Valuations and Transit Oriented Development. Retrieved from http://digital.library.unt.edu/ark:/67531/metadc30386/m1/2/

Weinstock, A., Hook, W., Replogle, M., \& Cruz, R. (2011). Recapturing Global Leadership in Bus Rapid Transit. New York, NY.

Wirasinghe, S. C., Kattan, L., Rahman, M. M., Hubbell, J., Thilakaratne, R., \& Anowar, S. (2013). Bus rapid transit - a review. International Journal of Urban Sciences, 17(1), 1-31. http://doi.org/10.1080/12265934.2013.777514

Wright, L., \& Hook, W. (2007). Bus Rapid Transit Planning Guide. New York, NY. Retrieved from https://www.itdp.org/wp-content/uploads/2014/07/Bus-Rapid-Transit-Guide-CompleteGuide.pdf

Yazici, M., Levinson, H., Ilicali, M., Camkesen, N., \& Kamga, C. (2013). A Bus Rapid Transit Line Case Study: Istanbul's Metrobüs System. Journal of Public Transportation, 16(1), 153-177. Retrieved from http://www.nctr.usf.edu/wp-content/uploads/2013/03/16.1_yazici.pdf 